\title{
PENGEMBANGAN LEMBAR KEGIATAN SISWA BERBASIS KEARIFAN LOKAL TEMA KEGEMARANKU SUBTEMA GEMAR BEROLAHRAGA \& GEMAR BERNYANYI DAN MENARI DI KELAS I SDN UTAMA 1 TARAKAN
}

\author{
Tiara Adi Pratiwi \\ Universitas Borneo Tarakan \\ robyznoer@gmail.com
}

\begin{abstract}
This research aims to produce students' worksheet based on local wisdom for first grade on theme my hobbies subtheme love in doing sports\& singing and dancing of SDN Utama 1 Tarakan. This research was Research and Development with adopt procedure from Borg and Gall which is potential and problem, gather information, product design, design validation, the revised design, product testing, product revision, testing usage, and product revision. This result showed that : (a) student worksheet included in the category of valid from aspect content and material with average score 4,44 category very good, aspect language with average score 4 category good, and aspect desain with average score 4,04 category very good (b) student worksheet included in the category of practic with average score 3,83 category good (c) student worksheet included in the category effective from aspect observation student activity with average score 3,45 category good, aspect student respons with average score 4,32 category very good, and aspect of students learning outcomes with average score 4,74 category very good.
\end{abstract}

Keyword: Student Worksheet, Local Culture

\begin{abstract}
ABSTRAK
Penelitian ini bertujuan untuk menghasilkan lembar kegiatan siswa berbasis kearifan lokal untuk kelas I pada tema kegemaranku subtema gemar berolahaga \& gemar bernyanyi dan menari di SDN Utama 1 Tarakan dan menghasilkan LKS yang layak untuk digunakan. Penelitian ini mengadopsi prosedur penelitian dan pengembangan (research and development) dari Borg and Gall, yang terdiri dari potensi dan masalah, mengumpulkan informasi, desain produk, validasi desain, revisi desain, ujicoba produk, revisi produk, ujicoba pemakaian, dan revisi produk Hasil penelitian menunjukan bahwa: (a) LKS termasuk dalam kategori valid dari aspek isi dan materi dengan skor rata-rata 4,44 kategori sangat baik, aspek bahasa dengan skor rata-rata 4 kategori baik dan aspek desain dengan skor rata-rata 4,04 kategori sangat baik (b) LKS termasuk dalam kategori praktis dengan skor rata-rata 3,83 kategori baik (c) LKS termasuk dalam kategori efektif dari aspek pengamatan aktivitas siswa dengan skor rata-rata 3,45 kategori baik, aspek respon siswa dengan rata-rata skor 4,32 kategori sangat baik, dan aspek hasil belajar siswa dengan rata-rata skor 4,74 kategori sangat baik.
\end{abstract}

Kata Kunci: Lembar Kerja Siswa, Kearifan Lokal 
147 | Premiere Educandum, Volume 6 Nomor 2, Desember 2016, 146 - 161

\section{A. PENDAHULUAN}

Kurikulum 2013 merupakan kurikulum baru yang mulai diterapkan pada tahun pelajaran 2013/2014. Kurikulum 2013 adalah sebuah kurikulum yang dikembangkan untuk meningkatkan dan menyeimbangkan kemampuan soft skills dan hard skills yang berupa sikap, pengetahuan, dan keterampilan. Selain itu, pembelajaran lebih bersifat tematik integratif dalam semua mata pelajaran. Tematik integratif adalah pembelajaran yang menggunakan tema dalam mengaitkan beberapa materi ajar sehingga dapat memberikan pengalaman bermakna pada siswa (Khoiru, 2014: 83).

Penerapan kurikulum 2013 di sekolah dasar didampingi dengan buku siswa dan buku guru untuk setiap jenjang dan kelas. Implementasi kurikulum 2013 di sekolah dasar dilakukan dengan mengacu pada daftar tema yang telah ditentukan oleh kementerian pendidikan dan kebudayaan (Kemendikbud) Republik Indonesia. Kemendikbud menerbitkan buku seri pembelajaran tematik untuk pegangan guru dan siswa. Buku tersebut diterbitkan untuk tiap tema, bukan tiap mata pelajaran. Jumlah tema di setiap jenjang kelas berbedabeda.

Permasalahan di sekolah pada SD Negeri Utama 1 Tarakan adalah kurang relevannya buku pendamping dengan kondisi nyata dilingkungan siswa dan guru. Buku pendamping terbitan nasional, umumnya memiliki isi yang kurang sesuai dengan situasi, kondisi, kemampuan siswa, guru dan sekolah. Padahal, lingkungan, karakteristik dan kebutuhan siswa di setiap daerah tentu berbeda-beda. Sehingga LKS yang digunakan juga berbeda. Selain itu buku pendamping yang ada tidak mengintegrasikan mata pelajaran PJOK. Oleh karena itu, perlu usaha untuk membuat LKS yang sesuai dengan situasi, kondisi, kemampuan siswa, guru dan sekolah. Peneliti bersama rekan membentuk suatu tim yang bermaksud untuk melakukan penelitian pengembangan LKS. Alasan kami melakukan penelitian ini secara tim adalah untuk memperoleh pengembangan LKS yang komprehensif dan optimal. Setiap 
Roby Zulkarnain Noer dan Tiara Adi Pratiwi: Pengembangan Lembar ... |148

anggota tim memiliki tugas dan garapan penelitian masing-masing. Peneliti sendiri dalam hal ini berfokus pada pengembangan bahan ajar berupa LKS pada tema kegememaranku subtema gemar berolahraga \& gemar bernyanyi dan menari. Dari hal-hal yang peneliti jelaskan, akhirnya peneliti terdorong untuk melakukan penelitian mengenai "Pengembangan Lembar Kegiatan Siswa Berbasis Kearifan Lokal Tema Kegemaranku Pada Subtema Gemar Berolahraga \& Gemar Bernyanyi dan Menari di Kelas I SDN Utama 1 Tarakan”.

\section{B. METODE PENELITIAN}

Jenis penelitian yang dilakukan dalam penelitian ini yaitu penelitian pengembangan (research and development/R \& D). Dalam bidang pendidikan, Borg ang Gall dalam Sugiyono (2013: 4) menyatakan bahwa, penelitian dan pengembangan (research and development/R \& D) merupakan metode penelitian yang digunakan untuk megembangkan atau memvalidasi produk-produk yang digunakan dalam pendidikan dan pembelajaran. Menghasilkan produk tertentu dapat menggunakan penelitian yang bersifat analisis kebutuhan dan untuk menguji keefektifan produk tersebut supaya dapat berfungsi disekolah dasar, maka diperlukan penelitian untuk menguji kelayakan produk tersebut.

Prosedur penelitian pengembangan ini menggunakan model pengembangan meliputi research and development $/ R \& D$, yang terdiri atas 10 tahap. Pada pengembangan bahan ajar ini peneliti hanya melaksanakan 9 tahap yaitu, 1) Potensi dan masalah, mengumpulkan informasi, 3) desain produk, 4) validasi desain, 5) revisi desain, 6) ujicoba produk, 7) revisi produk, 8) ujicoba pemakaian, dan 9) revisi produk. Tahap-tahap research and development $/ R \& D$ secara rinci dapat dijelaskan berikut ini:

1. Potensi dan Masalah

Tahapan potensi dan masalah dilakukan untuk memperoleh kajian terhadap bahan ajar LKS meliputi: (a) studi literatur untuk mungumpulkan sumber mengenai panduan menyusun LKS, pengumpulan penelitian yang relevan, dan pengumpulan buku-buku yang berkaitan dengan LKS (b) Studi lapangan, peneliti melakukan 
149 | Premiere Educandum, Volume 6 Nomor 2, Desember 2016, 146 - 161

observasi guna menganalisis LKS atau buku pendamping yang digunakan dan mengamati proses belajar mengajar di kelas.

2. Mengumpulkan informasi

Tahap ini, dimulai dari melakukan analisis bahan ajar LKS. Ada beberapa hal yang dilakukan peneliti yaitu, melakukan analisis pembelajaran tema kegemaranku (keterkaitan kompetensi inti, kompetensi dasar, dan indikator) serta menyusun rincian dan pemetaan kompetensi dasar.

\section{Desain produk}

Rencana disusun berdasarkan analisis respon terhadap LKS yang pernah dipakai oleh guru dan siswa untuk mengetahui kelemahan LKS yang pernah digunakan kemudian melakukan penyusunan LKS.

a. Menyusun desain LKS

LKS yang dihasilkan bermanfaat dan menarik perhatian siswa untuk belajar maka perlu memperhatikan desain pengembangan LKS seperti, menentukan ukuran kertas, kepadatan halaman, penomoran, dan pemilihan warna.

b. Pengembangan desain LKS
Mengembangkan LKS yang menarik dan dapat digunakan secara maksimal oleh siswa dalam kegiatan pembelajaran, peneliti harus menentukan tujuan pembelajaran yang akan dimasukkan ke dalam LKS, pengumpulan materi dan tugas, dan penyusunan elemen atau unsurunsur.

4. Validasi desain

Menilai apakah rancangan produk yang telah dibuat akan lebih efektif atau tidak. Validasi desain dilakukan dengan cara menghadirkan beberapa ahli yang sudah berpengalaman untuk menilai produk yang dirancang. Uji validitas diberikan kepada 5 ahli. Ahli pertama dan kedua akan memvalidasi isi \& materi pada LKS. Tujuannya adalah untuk mengetahui hasil produk tersebut sudah sesuai dengan lingkungan, karakteristik dan kebutuhan siswa.

Ahli ketiga akan memfokuskan pada aspek bahasa yang digunakan dalam produk. Tujuannya adalah untuk mengetahui apakah bahasa yang digunakan dalam produk baik atau tidak, dipahami dan mudah diserap oleh siswa sekolah dasar. 
Ahli keempat dan kelima akan memfokuskan pada aspek validasi desain. Memvalidasi desain harus memilih orang yang ahli desain LKS. Validasi desain ini dilakukan guna melihat ketertarikan tampilan produk.

\section{Revisi Desain}

Peneliti merevisi LKS, sesuai dengan kekurangan-kekurangan dan kesalahan-kesalahan setelah di validasi oleh ahli dan guru.

6. Ujicoba Produk

LKS yang telah direvisi oleh peneliti, akan di ujicoba kepada siswa sekolah dasar. Pada tahap ini akan dilakukan pengujian secara terbatas. Ujicoba pertama dilakukan terhadap satu orang siswa (one-to-one testing). Maksud dari ujicoba terhadap seorang siswa ini bukan untuk menguji siswa tetapi untuk menguji produk. Siswa yang dipilih untuk keperluan ujicoba sebaiknya bukan yang terlalu pandai dan bukan yang terlalu sedikit pengetahuannya. Ujicoba pada tahap ini tidak perlu diakhiri dengan mengerjakan tes, karena yang terpenting adalah meyakinkan bahwa siswa dapat memahami apa yang ia baca dan melaksanakan tugas yang dituliskan. Pendapat dari pengguna lebih diutamakan sebagai bahan untuk revisi (Harjanto, 2000: 290).

Setelah melalui ujicoba terhadap seorang, dan telah direvisi sesuai dengan data yang diperoleh dari siswa tersebut, selanjutnya melaksanakan ujicoba terhadap sekelompok kecil siswa. Ujicoba dilakukan terhadap $5-8$ orang siswa yang memiliki kemampuan rata-rata. Pada tahap ini siswa berperan sebagai advisors, menunjukkan kepada penyusun bagian produk yang kurang atau lemah (Harjanto, 2000: 292). Tujuan dilakukan ujicoba ini adalah untuk mengetahui apakah bahan ajar yang telah dibuat sudah sesuai dengan lingkungan, karakteristik dan kebutuhan siswa.

\section{Revisi Produk}

Revisi produk dilakukan jika LKS telah diujicoba dalam pemakaian yang lebih luas (minimal satu kelas). Jika ditemukan kekurangan atau kelemahan atau belum memenuhi spesifikasi produk yang diharapkan, maka perlu dikoreksi dan revisi demi kesempurnaan LKS yang disusun. Setelah produk direvisi, maka produk tersebut di ujicoba pemakaiannya. 
8. Ujicoba Pemakaian

Pelaksanaan ujicoba pemakaian dilaksanakan terhadap 20 sampai dengan 25 orang siswa atau lebih. Maksud dari ujicoba pemakaian ialah untuk memperoleh validitas LKS, untuk menentukan apakah LKS efektif, dan siswa dapat mencapai kompetensi sesuai LKS (Harjanto, 2000: 294). Setelah pengujian terhadap produk berhasil, dan mungkin ada sedikit revisi, maka selanjutnya produk tersebut dapat diterapkan dalam kondisi nyata untuk lingkup yang luas.

\section{Revisi Produk}

Revisi produk ini dilakukan, apabila setelah ujicoba pemakaian masih terdapat kelemahan, maka perlu direvisi lagi, yang bersifat revisi final. Setelah produk direvisi, maka selanjutnya produk disebarluaskan dan diimplementasikan di sekolah atau masyarakat.
Setelah melewati sembilan tahap, peneliti melakukan evaluasi untuk menguji kepraktisan dan keefektifan implementasi LKS dan evaluasi terhadap LKS yang dikembangkan di sekolah dasar. Jika LKS telah dinyatakan layak, maka dilakukan penyempurnaan untuk menghasilkan LKS tematik. Tahaptahap penelitian pengembangan yang telah dipaparkan

\section{HASIL PENELITIAN}

1. Validasi Isi dan Materi

Desain produk yang dibuat dinilai oleh ahli pembelajaran. Ahli dipilih dengan kriteria yang telah ditentukan yaitu dosen pendidikan bidang studi dari universitas kependidikan dan guru mata pelajaran berpendidikan minimal $\mathrm{S} 1$ dengan pengalaman mengajarkan pelajaran dalam lima tahun terakhir (BSNP, 2007: 22). Oleh karena itu validasi isi dan materi LKS akan dilakukan oleh dua ahli terpilih. 
Roby Zulkarnain Noer dan Tiara Adi Pratiwi: Pengembangan Lembar... |152

Tabel 1. Hasil Validasi Isi dan Materi LKS

\begin{tabular}{|c|c|c|c|}
\hline \multirow[t]{2}{*}{ No } & \multirow[t]{2}{*}{ Aspek yang dinilai } & \multirow{2}{*}{$\begin{array}{l}\text { Skor } \\
\text { Ahli } \\
1\end{array}$} & \multirow{2}{*}{$\begin{array}{c}\text { dari } \\
2 \\
\end{array}$} \\
\hline & & & \\
\hline \multicolumn{4}{|c|}{ Penyajian Materi } \\
\hline 1 & $\begin{array}{l}\text { Materi yang disajikan pada LKS sesuai dengan Kompetensi } \\
\text { Inti dan Kompetensi Dasar. }\end{array}$ & 5 & 4 \\
\hline 2 & $\begin{array}{l}\text { Materi yang disajikan bersifat aktif, menyenangkan, dan } \\
\text { autentik }\end{array}$ & 5 & 4 \\
\hline 3 & $\begin{array}{l}\text { Materi yang disajikan sesuai dengan tingkat pemikiran siswa } \\
\text { SD }\end{array}$ & 5 & 4 \\
\hline \multicolumn{4}{|c|}{ Penyajian Soal } \\
\hline 4 & $\begin{array}{l}\text { Soal-soal pada LKS sesuai dengan Kompetensi Inti dan } \\
\text { Kompetensi Dasar }\end{array}$ & 5 & 4 \\
\hline \multicolumn{4}{|c|}{ Fungsi LKS } \\
\hline 5 & LKS dapat berfungsi sebagai penuntun belajar & 5 & 4 \\
\hline 6 & LKS dapat berfungsi sebagai penguatan materi & 5 & 4 \\
\hline \multicolumn{4}{|c|}{ Isi LKS } \\
\hline 7 & $\begin{array}{l}\text { LKS menyajikan tugas yang dapat meningkatkan } \\
\text { penguasaan materi peserta didik }\end{array}$ & 4 & 4 \\
\hline 8 & $\begin{array}{l}\text { LKS memuat materi yang berisi kearifan lokal yang sesuai } \\
\text { dengan lingkungan, karakteristik dan kebutuhan siswa }\end{array}$ & 5 & 4 \\
\hline & Jumlah & 39 & 32 \\
\hline & Rerata Skor & \multicolumn{2}{|c|}{4,43} \\
\hline & Kriteria & \multicolumn{2}{|c|}{ Sangat Baik } \\
\hline
\end{tabular}

2. Validasi Bahasa

Pada LKS terdapat empat sub indikator yang di nilai oleh ahli bahasa yaitu konsistensi, bentuk huruf, struktur kalimat, dan penggunaan bahasa. Masing-masing sub indikator memiliki aspek penilaian yang rinciannya dapat dilihat pada Tabel 2. Validasi bahasa dilakukan oleh dosen pendidikan bidang studi dari universitas kependidikan (BSNP, 2007: 22). Dalam hal ini validasi dilakukan oleh ibu Siti Fatonah, M. Pd, selaku dosen di jurusan pendidikan bahasa dan sastra Indonesia Universitas Borneo Tarakan. Hasil validasi oleh ahli bahasa dapat dilihat pada Tabel 2 berikut. 
153 | Premiere Educandum, Volume 6 Nomor 2, Desember 2016, 146 - 161

Tabel 2. Hasil Validasi Bahasa LKS

\begin{tabular}{|c|c|c|}
\hline No & Aspek yang dinilai & $\begin{array}{l}\text { Skor } \\
\text { Ahli }\end{array}$ \\
\hline \multicolumn{3}{|c|}{ Konsistensi } \\
\hline 1 & Menggunakan kata, istilah, dan kalimat yang konsisten & 4 \\
\hline 2 & Menggunakan bentuk dan ukuran huruf yang konsisten & 4 \\
\hline \multicolumn{3}{|c|}{ Bentuk Huruf } \\
\hline 3 & Bentuk dan ukuran huruf mudah di baca & 4 \\
\hline 4 & Ukuran huruf yang digunakan proposional & 4 \\
\hline \multicolumn{3}{|c|}{ Struktur Kalimat } \\
\hline 5 & Menggunakan struktur kalimat yang jelas dan tepat & 4 \\
\hline 6 & Kalimat singkat dan lugas & 4 \\
\hline 7 & $\begin{array}{l}\text { Menggunakan kosa kata yang sesuai dengan tingkat } \\
\text { perkembangan siswa }\end{array}$ & 4 \\
\hline \multicolumn{3}{|c|}{ Penggunaan Bahasa } \\
\hline 8 & Bahasa yang digunakan baik dan benar & 4 \\
\hline 9 & Bahasa yang digunakan sederhana, jelas dan mudah dipahami & 4 \\
\hline & Jumlah & 36 \\
\hline & Rerata Skor & 4 \\
\hline & Kriteria & Baik \\
\hline
\end{tabular}

\section{Validasi Desain}

Desain merupakan salah satu faktor pendukung dari LKS yang dibuat. Validasi desain ini dilakukan guna melihat ketertarikan tampilan produk. Memvalidasi desain harus memilih orang yang ahli desain LKS. Desain divalidasi oleh ahli grafika (BSNP, 2007: 22). Ahli keempat yaitu Roman Gusmana, S. Kom, dosen dari Sekolah Tinggi Manajemen dan Ilmu Komunikasi PPKIA Tarakan dan ahli kelima yaitu Jimmy Sampe, S. Kom, staf TU SDN Utama 1 Tarakan. Indikator yang dinilai pada validasi desain yaitu tampilan, konsistensi, dan ilustrasi. Validasi desain oleh ahli dapat dilihat pada Tabel 3 berikut. 
Tabel 3. Hasil Validasi Desain LKS

\begin{tabular}{|c|c|c|c|}
\hline \multirow{2}{*}{ No } & \multirow{2}{*}{ Aspek yang dinilai } & \multicolumn{2}{|c|}{ Skor dari Ahli } \\
\hline & & 1 & 2 \\
\hline \multicolumn{4}{|c|}{ Tampilan } \\
\hline 1 & Ukuran kertas & 5 & 4 \\
\hline 2 & Kepadatan halaman & 5 & 3 \\
\hline 3 & Ruang dan tata letak & 4 & 4 \\
\hline 4 & Kesesuaian jenis dan ukuran huruf & 4 & 3 \\
\hline 5 & Penomoran & 4 & 4 \\
\hline 6 & Pemilihan warna & 4 & 5 \\
\hline 7 & Kejelasan Cetakan & 3 & 4 \\
\hline 8 & Mudah dibaca & 4 & 4 \\
\hline \multicolumn{4}{|c|}{ Konsistensi } \\
\hline 9 & Format dari halaman ke halaman & 4 & 4 \\
\hline 10 & Jarak dan spasi & 4 & 3 \\
\hline \multicolumn{4}{|c|}{ Ilustrasi } \\
\hline 11 & Menarik & 4 & 5 \\
\hline 12 & Sesuai dengan materi & 4 & 5 \\
\hline 13 & Komunikatif & 4 & 4 \\
\hline & Jumlah & 53 & 52 \\
\hline & Rerata Skor & \multicolumn{2}{|c|}{4,03} \\
\hline & Kriteria & \multicolumn{2}{|c|}{ Sangat Baik } \\
\hline
\end{tabular}

4. Hasil dan Pembahasan Uji ujicoba skala kecil. Setelah desain Kepraktisan

produk direvisi LKS diujicobakan

Terkait dengan aspek pada tahap ujicoba pemakaian. Pada kepraktisan, hasil penelitian Nieveen tahap inilah uji kepraktisan LKS dalam Hafiz (2013: 34) dilakukan dengan menggunakan memperlihatkan cara mengukur instrumen pengamatan yang tingkat kepraktisan. Hasil penelitian diberikan kepada pengamat atau ini menjelaskan bahwa tingkat observer untuk memberikan kepraktisan dilihat dari penjelasan penilaian. Uji kepraktisan apakah guru dan paka pakar lainnya dilaksanakan pada tanggal 14 memberikan pertimbangan bahwa November 2015 bertempat di ruang materi mudah dan dapat digunakan kelas I-B SDN utama 1 Tarakan, oleh guru dan siswa. Uji kepraktisan pukul 07.30 - 09.00. Hasil uji dilakukan setelah revisi pada tahap 
kepraktisan dapat dilihat pada tabel

11.

Tabel 4. Hasil Uji Kepraktisan LKS

\begin{tabular}{clcc}
\hline \multirow{2}{*}{ No } & \multicolumn{1}{c}{ Aspek yang dinilai } & \multicolumn{2}{c}{ Skor dari Pengamat } \\
\cline { 3 - 5 } & \multicolumn{1}{c}{$\mathbf{1}$} & $\mathbf{2}$ \\
\hline 1 & Siswa dapat membaca LKS dengan mudah & 4 & 4 \\
2 & Siswa tertarik dengan penampilan LKS & 4 & 4 \\
3 & Siswa dapat belajar secara terarah & 3 & 4 \\
4 & $\begin{array}{l}\text { Siswa mendapatkan penguatan materi dengan } \\
\text { bantuan LKS }\end{array}$ & 3 & 4 \\
5 & $\begin{array}{l}\text { Siswa dapat melakukan langkah kegiatan } \\
\text { dengan mudah }\end{array}$ & 4 & 4 \\
6 & LKS dapat digunakan dengan mudah & 5 & 4 \\
\hline \multicolumn{2}{c}{ Jumlah } & $\mathbf{2 2}$ & $\mathbf{2 4}$ \\
\hline \multicolumn{3}{c}{ Kerata Skor } & \multicolumn{3}{c}{ Baik } \\
\hline
\end{tabular}

\section{PEMBAHASAN}

Hasil penilaian validasi LKS oleh ahli 1 dapat diketahui bahwa dari 8 aspek yang dinilai mendapat skor penilaian yang baik yang berkisar antara 4-5. Penilaian dari ahli menunjukkan bahwa indikator dari penyajian materi dan penyajian soal mendapatkan nilai sangat baik. Penyajian materi pada LKS, telah sesuai dengan standar isi (kompetensi inti dan kompetensi dasar) dan materi yang disajikan sesuai dengan tingkat pemikiran siswa SD. Penyajian soal dinyatakan sudah sesuai dengan standar isi (kompetensi inti dan kompetensi dasar) dan layak digunakan dalam penelitian. Latihan soal pada LKS berperan dalam mengukur hasil kegiatan belajar pada siswa.

Pembelajaran berbasis kontekstual membantu siswa menghubungkan pelajaran dengan kehidupan siswa. Siswa tidak hanya mendapatkan informasi tetapi juga belajar menggunakan keterampilan dan membantu siswa mencapai tujuan pembelajaran (Johnson, 2002: 275). LKS yang dikembangkan sudah memuat materi berbasis kearifan lokal kota Tarakan. Penyajian materi berbasis kearifan lokal dapat manambah informasi siswa mengenai kebudayaan daerah Tarakan. Materi dan penyajian gambar pada LKS mencerminkan lingkungan belajar 
Roby Zulkarnain Noer dan Tiara Adi Pratiwi: Pengembangan Lembar ... |156

siswa yaitu lingkungan sekolah SDN

Utama 1 Tarakan. Mengaitkan pembelajaran dengan kehidupan siswa membuat proses belajar menjadi hidup

Prastowo

(2011:

menyatakan bahwa setiap LKS disusun dengan materi dan tugas tertentu yang dikemas sedemikian rupa untuk tujuan dan fungsi tertentu. Berdasarkan pernyataan tersebut indikator fungsi LKS mendapatkan nilai sangat baik, karena LKS dapat berfungsi sebagai penuntun belajar dan sebagai penguatan materi. Indikator isi LKS mendapat penilaian sangat baik dari ahli karena tugas yang disajikan dalam LKS dapat meningkatkan penguasaan siswa terhadap materi yang diberikan. Jumlah nilai yang diberikan oleh ahli 1 yaitu 39 dan ahli 2 yaitu 32. Skor dari ahli 1 dan ahli 2 kemudian dicara rerata skornya. Rerata skor yang diperoleh yaitu 4,43 dengan kriteria sangat baik.

Validasi bahasa dinyatakan lolos penilaian apabila indikator keterbacaan, kesesuaian dengan kaidah bahasa Indonesia yang baik dan benar dan logika berbahasa mempunyai rata-rata skor lebih besar dari 2,50 (BSNP, 2007: 21). Diketahui dari 9 aspek yang dinilai mendapat skor penilaian yang baik, karena berisi informasi, pesan, dan pengetahuan yang dituangkan dalam bentuk tertulis yang dapat dikomunikasikan kepada pembaca (khususnya guru dan peserta didik) secara logis, mudah diterima sesuai dengan tahapan perkembangan kognitif pembaca dan telah sesuai dengan kaidah bahasa Indonesia yang baik dan benar. Adapun komentar atau saran yang diberikan oleh ahli bahasa yaitu perbaikan tehadap pemberian tanda baca, perbaikan ejaan yang salah, perbaikan kalimat dan perbaikan tata letak. Rerata skor yang diperoleh dari validasi bahasa yaitu 4 dengan kriteria baik. LKS dinyatakan lolos penilaian kelayakan bahasa.

Menurut Prastowo (2011: 2016) ukuran LKS yang proporsional, halaman yang tidak terlalu padat dengan tulisan, penomoran pada subjudul dan kegiatan, serta kejelasan instrusi dalam LKS, merupakan komponen yang mempengaruhi tingkat kemudahan siswa dalam 
menggunakan dan memahami materi dalam LKS secara mandiri. Hasil penilaian desain LKS oleh ahli desain diketahui bahwa dari 13 aspek yang dinilai didapatkan kisaran skor 3-5, karena penggunaan kertas ukuran A4 dapat mengakomodasi ruang untuk meletakkan komponen LKS dalam bentuk tulisan, ruang gambar, dan tabel. Dari aspek kepadatan halaman, LKS tidak terlalu padat dengan kajian. Persebaran ruang dan tata letak mewarnai, tabel dan gambar dapat mengurangi kesan padat tulisan pada LKS. Kesesuaian jenis dan ukuran huruf, dan kejelasan cetakan disajikan secara jelas dan mudah untuk dibaca. Komposisi warna dan penambahan ikon gambar berciri khas Tarakan menjadi salah satu daya tarik LKS. Pemberian urutan nomor sesuai dengan urutan materi dapat membantu siswa untuk belajar secara sistematis dan memmahami keseluruhan materi. Ilustrasi disajikan secara menarik dan sesuai dengan materi, sehingga dapat membantu siswa mengingat materi yang disajikan.

Adapun beberapa komentar dan saran perbaikan yang diberikan oleh ahli yaitu, ukuran tulisan lebih diperbesar agar sesuai dengan jenjang pendidikan siswa, karakter pada sampul kurang ditonjolkan pada LKS, header and footer kurang konsisten, beberapa icon memiliki komposisi warna yang kurang atau tidak kontras dengan warna font, dan tata letak beberapa icon kurang baik. Komentar yang diberikan oleh ahli akan di gunakan oleh peneliti sebagai bahan perbaikan pada tahan revisi desain. Validasi desain dinyatakan lolos penilaian apabila rata-rata skor lebih besar dari 2,50 (BSNP, 2007: 21). Hasil penilaian oleh ahli pada tabel 10 menunjukan nilai antara 3-5 dengan jumlah nilai dari ahli 4 yaitu 53 dan dari ahli 5 yaitu 52. Rerata skor yang diperoleh dari ahli 4 dan ahli 5 yaitu 4,03 dengan kriteria sangat baik.

Nieven dalam Hafiz (2013: 34) juga menjelaskan, produk hasil pengembangan, disimpulkan praktis jika praktisi menyatakan secara teoretis produk dapat diterapkan di lapangan dan tingkat keterlaksanaannya produk termasuk kategori "baik". Tabel 4 memperlihatkan hasil uji kepraktisan oleh pengamat 1 dan 2. Pengamat 
memberikan skor berkisar 3-5. Ratarata uji kepraktisan yang diperoleh yaitu 3,83 dengan kriteria baik, oleh karena itu LKS dapat dinyatakan praktis. Hal ini berarti LKS dapat dibaca dengan mudah oleh siswa, siswa tertarik dengan penampilan LKS, LKS bisa membantu siswa belajar secara terarah, LKS bisa membantu siswa mendapatkan penguatan materi, LKS dapat digunakan dengan mudah oleh siswa.

\section{E. SIMPULAN DAN SARAN}

\section{Simpulan}

\begin{tabular}{ccc}
\multicolumn{2}{c}{ Berdasarkan } & hasil \\
pengembangan & LKS & tema
\end{tabular} kegemaranku berbasis kearifan lokal tema kegemaranku subtema gemar berolahraga dan gemar bernyanyi dan menari di kelas I SDN Utama 1 Tarakan memberikan kesimpulan sebagai berikut.

1. Pengembangan LKS tema kegemaranku berbasis kearifan lokal tema kegemaranku subtema gemar berolahraga dan gemar bernyanyi dan menari di kelas I telah melewati 9 tahap, yaitu potensi dan masalah, mengumpulkan informasi, desain produk, validasi desain, revisi desain, ujicoba produk, revisi produk, ujcoba pemakaian, dan revisi produk. Setelah melewati sembilan tahap tersebut terbentuklah LKS tematik tema kegemaranku subtema gemar berolahraga \& gemar bernyanyi dan menari untuk kelas I SD.

2. Hasil pengembangan LKS tema kegemaranku berbasis kearifan lokal tema kegemaranku subtema gemar berolahraga dan gemar bernyanyi dan menari di kelas I termasuk dalam kategori valid karena:

a. Validasi isi dan materi memperoleh rata-rata skor 4,43 dengan kategori sangan baik karena penyajian materi dan latihan soal pada LKS, telah sesuai dengan standar isi (kompetensi inti dan kompetensi dasar), materi yang disajikan sesuai dengan tingkat pemikiran siswa SD, latihan soal pada LKS berperan dalam mengukur hasil kegiatan belajar pada siswa. LKS dapat berfungsi sebagai penuntun belajar dan sebagai penguatan materi. 
b. Validasi bahasa memperoleh rata-rata skor 4 dengan kategori baik karena informasi, pesan, dan pengetahuan yang dituangkan dalam bentuk tertulis yang dapat dikomunikasikan kepada pembaca secara logis, mudah diterima sesuai dengan tahapan perkembangan kognitif siswa SD dan telah sesuai dengan kaidah bahasa Indonesia yang baik dan benar.

c. Validasi desain memperoleh rata-rata skor 4,03 dengan kategori sangat baik karena penggunaan kertas ukuran A4 dapat mengakomodasi ruang untuk meletakkan komponen LKS, persebaran ruang dan tata letak mewarnai, tabel dan gambar dapat mengurangi kesan padat tulisan, jenis dan ukuran huruf, dan kejelasan cetakan disajikan secara jelas dan mudah untuk dibaca, gambar berciri khas Tarakan menjadi salah satu daya tarik
LKS, dan penyajian ilustrasi yang menarik dapat membantu siswa mengingat materi yang disajikan.

\section{Saran}

Dari penelitian LKS tema kegemaranku subtema gemar berolahraga dan gemar bernyanyi dan menari untuk sekolah dasar kelas I diberikan saran sebagai berikut:

a. Pengembangan LKS tema kegemaranku subtema gemar berolahraga dan gemar bernyanyi dan menari untuk sekolah dasar kelas I sebaiknya memperhatikan kesesuaian isi dan integrasi antar mata pelajaran dengan kompetensi inti, kompetensi dasar, jaringan kompetensi dasar, dan indikator yang sesuai dengan kurikulum 2013.

b. Pengembangan LKS tema kegemaranku subtema gemar berolahraga dan gemar bernyanyi dan menari untuk sekolah dasar kelas I sebaiknya mengoptimalkan pemuatan materi dan ilustrasi yang berisi kearifan lokal kota Tarakan yang sesuai dengan 
Roby Zulkarnain Noer dan Tiara Adi Pratiwi: Pengembangan Lembar ... |160

lingkungan dan karakteristik siswa.

c. Pengembangan LKS sebaiknya menggunakan bahasa yang mudah dipahami siswa sesuai dengan tingkat pemikiran siswa sehingga informasi-informasi LKS dapat diserap dan dicerna dengan mudah oleh siswa.

\section{Daftar Rujukan}

Ahmadi, Iif Khoiru. 2014. Pengembangan \& Model Pembelajaran Tematik Integratif. Jakarta: Prestasi Pustaka Publisher.

-------. 2011. Mengembangkan Pembelajaran IPS Terpadu. Jakarta: Prestasi Pustaka Publisher.

Buletin BSNP. (2007). Kapal Itu Bernama UN. Jakarta: BSNP

Fitri, Deti. 2014. Pengembangan Lembar Kegiatan Siswa (LKS) Tematik Integratif Pada Materi Garis Paralel Untuk Sekolah Dasar Kelas IV. Skripsi. Universitas Bengkulu, Bengkulu. (http://repository.unib.ac.id/8 737/, diakses 5 Maret 2015)

Harjanto. 2000. Perencanaan Pengajaran. Jakarta: Rineka Cipta.

Haviz, Muhammad. 2013. Penelitian Di Bidang Kependidikan Yang Inovatif, Produktif Dan Bermakna. Jurnal Ilmu Pendidikan, (Online), 16 (1):
28-43, diakses 3 Desember 2015.

Johnson, B. Elaine. 2002 Contextual Teaching \& Learning Menjadikan Kegitan Belajar Mengajar mengasyikkan dan Bermakna. Bandung: Kaifa.

Mustofa, Muhammad. 2013 Pengembangan Lembar Kerja Siswa Berbasis Observasi Pada Taman Sekolah Sebagai Sumber Belajar Sains di SDN I Tinjomoyo. Skripsi. Universitas Negeri Semarang, Semarang.

(lib.unnes.ac.id/18650/1/4401 406067.pdf, diakses 11 Maret 2015)

Panduan Teknis Penilaian di Sekolah Dasar. 2013. Kementerian Pendidikan dn Kebudayaan Direktorat Jenderal Pendidikan Dasar Direktorat Pembinaan Sekolah Dasar.

Prastowo, A. 2011. Panduan Kreatif Membuat Bahan Ajar Kreatif. Jogjakarta: DIVA Press.

-------. 2013. Pengembangan Bahan Ajar Tematik. Jogjakarta: DIVA Press.

Purwanto, 2011. Prinsip-prinsip dan Teknik Evaluasi Pengajaran. Bandung: PT Remaja Rosdakarya.

Rohman, Muhammad. 2013. Strategi \& Desain Pengembangan Sistem Pembelajaran. Surabaya: Prestasi Pustaka Publisher.

Setyosari, Punaji. 2013. Metode Penelitian Pendidikan \& Pengembangan. Jakarta: 
$161 \mid$ Premiere Educandum, Volume 6 Nomor 2, Desember 2016, 146 - 161

Kencana Prenadamedia

Group.

Siregar, S. 2013. Statistik Parametrik.

Jakarta: Bumi Aksara.

Situmorang, Pasuria. 2013. Penelitian dan Pengembangan

(Research and

Development),(Online),(http:/

/terbangkania.blogspot.com/2

013/05/researchanddevelopm ent.html), diakses 8 April 2015.

Sudijono, Anas. 2001. Pengantar Evaluasi Pendidikan. Jakarta: PT. Raja Grafindo Persada.

Sugiyono. 2008. Metode Penelitian Bisnis. Bandung: Alfabeta.

--------. 2010. Metode Penelitian Pendidikan Pendidikan Kuantitatif, Kualitatif, dan $R$ \& D. Bandung: Alfabeta.

Sunyoto, Danang. 2013. Metode dan Instrumen Penelitian Ekonomi dan Bisnis. Yogyakarta: PT Buku Seru.

Widyantini, Theresia. 2013. Penyusuanan Lembar Kegiatan Siswa (LKS) Sebagai Bahan Ajar. Halaman 4.

Yana, Nur, Alam. 2014. Pengembangan Bahan Ajar Tematik Kelas I Melalui Pendekatan Kontekstual di SDN Utama 1 Tarakan. Skripsi. Universitas Negeri Borneo Tarakan, Tarakan (tidak dipublikasikan). 